15. Dilenge D, Heon M 1974 The internal carotid artery. In: Newton TH, Potts DG (eds) Radiology of the Skull and Brain. CV Mosby Co., New York, pp 1205-1215

16. Batton DG, Hellman J, Hernandez MJ, Maisels MJ 1983 Regional cerebral blood flow, cerebral blood velocity, and Pulsatility index in newborn dogs. Pediatr Res 17:908-912

17. Hansen NB, Stonestreet BS, Rosencrantz TS, Oh W 1983 Validity of Doppler measurements of anterior cerebral artery blood flow velocity: correlation with brain blood flow in piglets. Pediatrics 72:526-531

18. Rosenberg AA, Narayanan V, Jones MD Jr 1985 Comparison of anterior cerebral artery blood flow velocity and cerebral blood flow during hypoxia. Pediatr Res 19:67-70

19. Taylor PM, Egan TJ, Birchard EL, Bright NH, Wolfson JH 1961 Venous hypertension in the newborn infant associated with delayed clamping of the umbilical cord. Acta Paediatr Scand 50:149-159

20. Tunell R, Copher D, Persson B 1974 The pulmonary gas exchange and blood gas changes in connection to birth. In: Stetson JB, Swyer PR (eds) Neonatal
Intensive Care. Warren H Green, Inc, St Louis, MO, pp 89-106

21. Hägnevik K, Faxelius G, Irestedt L, Lagercrantz H, Lundell B, Persson B 1984 Catecholamine surge and metabolic adaptation in the newborn after vaginal delivery and cesarean section. Acta Paediatr Scand 73:602-609

22. Rahilly PM 1980 Effects of sleep stage and feeding on cranial blood flow of the human neonate. Arch Dis Child 55:265-270

23. Robinson RO, Rolfe P, Sutton P 1977 Non-invasive method for measuring intracranial pressure in normal newborn infants. Dev Med Child Neurol 19:305-308

24. Sonesson SE, Lundell BPW, Herin P 1986 Changes in intracranial arterial blood flow velocities during surgical ligation of the patent ductus arteriosus. Acta Paediatr Scand 75:36-42

25. Faxelius G, Lagercrantz H, Yao A 1984 Sympatoadrenal activity and peripheral blood flow after birth. Comparison in infants delivered vaginally and by cesarean section. J Pediatr 105:144-148

26. Moss AJ, Emmanouilides G, Duffie ER 1963 Closure of the ductus arteriosus in the newborn infant. Pediatrics 32:25-30

\title{
Announcement
}

\section{Transplacental Effects on Fetal Health}

The symposium will be held at the National Institutes of Health, Bethesda, MD on November 5-6, 1987. The purpose of this symposium is to present our current understanding of the mechanisms of action of biologic agents, the effects of disturbed maternal metabolism, and drug and chemical abuse on the developing fetus of humans and animals. Four major topics are: 1) Congenital Viral Infections 2) Congenital Bacterial and Other Infections 3) Metabolic, Drug and Chemical Teratogens 4) Genetic Engineering.

The symposium will be open and free-of-charge, and places will be reserved for at least 100 participants. Invitations will be given on a first-come basis. For further information contact: George Migaki, DVM, Registry of Comparative Pathology, Armed Forces Institute of Pathology, Washington, D.C. 20306-6000, (202)576-2452. 